\title{
Sequential Immobilization of ansa-Hafnocene Complexes for Propene Polymerization
}

Marius I. Arz, ${ }^{1,2}$ Tim Kratky, ${ }^{1}$ Sebastian Günther, ${ }^{1}$ Katia Rodewald, ${ }^{1}$ Thomas Burger,,${ }^{1,2}$ Manfred Heuberger, ${ }^{3}$ Bernhard Rieger ${ }^{1, *}$

${ }^{1}$ Technische Universität München, Department of Chemistry, Lichtenbergstraße 4, 85748 Garching bei München, Germany

${ }^{2}$ Technische Universität München, Catalysis Research Center, Ernst-Otto-Fischer-Straße 1, 85748 Garching bei München, Germany

${ }^{3}$ Empa, Swiss Federal Laboratories for Materials Science and Technology, Laboratory for Advanced Fibers, 9014 St. Gallen, Switzerland *e-mail: rieger@tum.de

Abstract: We report the immobilization of the ultrarigid ansa-hafnocene complexes rac$\left[\mathrm{Me}_{2} \mathrm{Si}\left(\mathrm{Ind}^{*}\right)_{2} \mathrm{HfCl}_{2}\right]$ (rac-1; Ind* = 7-(3',5'-Di-tert-butylphenyl)-4-methoxy-2-methylindenyl) on silica as hetereogeneous catalysts for propene polymerization. A sequential three-step synthesis on the siliceous surface led to pre-catalysts of the generalized structure $\mathrm{SiO}_{2}$ $\mathrm{Si}\left(\mathrm{Ind}^{*}\right)_{2} \mathrm{HfCl}_{2}$, which possess the silylene bridge of the substituted bis(indenyl) ligand directly attached to the surface. The immobilized pre-catalysts show very poor performance in the polymerization of propene, independent on the reaction conditions and the employed silica. Based on the results, we suggest that the close proximity of the catalyst to the surface combined with the steric congestion provoked by the ligand prevents a continuous polymerization, most likely due to a blockage of the catalytically active sites with growing polymer.

TOC:
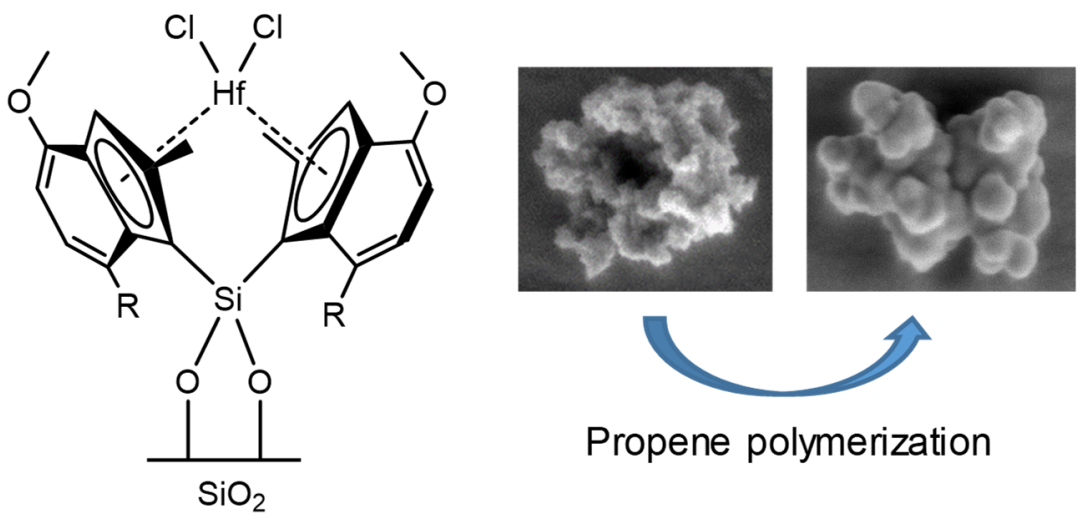

Propene polymerization

This document is the accepted manuscript version of the following article:

Arz, M. I., Kratky, T., Günther, S., Rodewald, K., Burger, T., Heuberger, M., \& Rieger, B.

(2019). Sequential immobilization of ansa-hafnocene complexes for propene polymerization.

Journal of organometal1ic chemistry, 121075 (4 pp.).

https://doi .org/10.1016/j.jorganchem.2019.121075

This manuscript version is made available under the CC-BY-NC-ND 4.0

license http://creativecommons.org/licenses/by-nc-nd/4.0/ 
The immobilization of homogeneous catalysts onto heterogeneous carriers is an important approach to unify homogeneous with heterogeneous catalysis. ${ }^{[1]}$ Catalysts for $\alpha$-olefin polymerization range amongst the most widely used catalysts due to the tremendous importance of polyolefins where polyethene (PE), polypropene (PP) and polystyrene (PS) alone contribute with $>50 \%$ to the overall global plastic production with ever-increasing demand. ${ }^{[2]}$ The immobilization of homogeneous $\alpha$-olefin polymerization catalysts is appealing, because it potentially enables the unification of the high activity and control of the polymer microstructure as well as the molecular weight provided by homogeneous single-site catalysts with the unmatched operability of heterogeneous Ziegler-Natta catalysts at industrial process conditions. ${ }^{[3]}$ Consequently, a wide range of strategies were explored to immobilize these single-site polymerization catalysts, including physiosorption, grafting and tethering of either the pre-catalyst or the activator reagent (co-catalyst). ${ }^{[1,3]}$

The continuous optimization of Group 4 ansa-metallocenes has attracted considerable attention in the last ca. 30 years, which culminated in the rise of $\mathrm{Zr}$ and $\mathrm{Hf}$ metallocenes with tailored silylene-bridged substituted indenyl ligands to be one of the most frequently used homogeneous polymerization catalysts. ${ }^{[4]}$ More recently, significant progress was also achieved in the development of post-metallocene catalysts. ${ }^{[5]}$

In 2012, we reported the synthesis of the ultrarigid hafnocene pre-catalyst rac$\left[\mathrm{Me}_{2} \mathrm{Si}\left(\mathrm{Ind}^{*}\right)_{2} \mathrm{HfCl}_{2}\right]$ (rac-1; Ind ${ }^{*}=7$-(3',5'-Di-tert-butylphenyl)-4-methoxy-2-methylindenyl), which produces isotactic polypropene (iPP) of ultrahigh molecular weight $\left(M_{w}>5 \cdot 10^{6} \mathrm{~g} / \mathrm{mol}\right)$ with nearly perfect stereocontrol $([\mathrm{mmmm}]>99.9 \%)$, providing iPP with the so far highest melting point ex reactor of $171^{\circ} \mathrm{C} .{ }^{[6]}$

Herein, we report our attempts to immobilize the catalyst rac-1 on silica particles using the sequential approach outlined in Scheme 1. This approach has been reported earlier for surface-tethering of zirconocene catalysts, but using only the unsubstituted indenyl (Ind, $\left.\mathrm{C}_{9} \mathrm{H}_{7}\right)$ as ligand, which induces no stereoselectivity in the metallation step and consequently leads to an undesired mixture of atactic (aPP) and isotactic polypropene (iPP) after propene polymerization. ${ }^{[7]}$ By contrast, the particular substitution pattern of the Ind* ligand favours a racemo-selective formation of rac-1, ${ }^{[6]}$ which is why we set out to explore the suitability of this rather simple approach to support rac-1 on silica. 


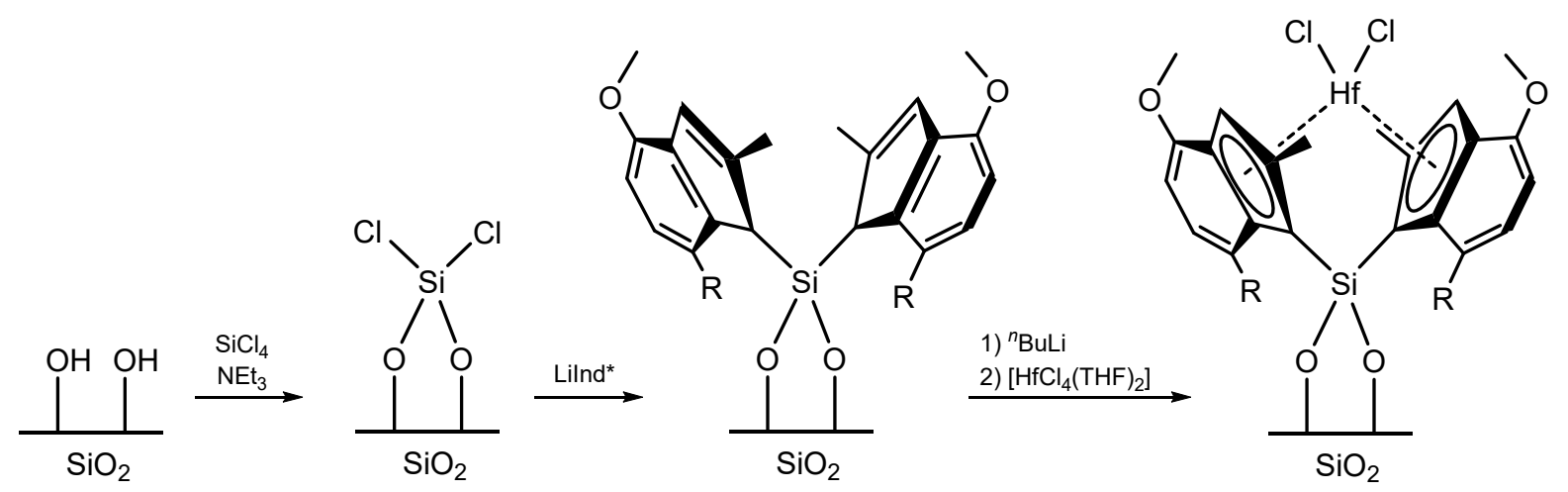

Scheme 1. Sequential approach for supporting the pre-catalyst rac-1 onto silica; $R=3,5-t \mathrm{Bu}_{2}-$ $\mathrm{C}_{6} \mathrm{H}_{3}$.

Two commercially available silicas were used in this study, namely Sipernat $₫ 50$ from Evonik $\left(a_{\mathrm{BET}}=450 \mathrm{~m}^{2} / \mathrm{g}\right.$, cumulative pore volume $=1.75 \mathrm{~mL} / \mathrm{g} ; a_{\mathrm{BET}}=$ surface area determined by BET analysis) and Sylopol $\circledast 2408 \mathrm{HT}$ from Grace $\left(a_{\mathrm{BET}}=310 \mathrm{~m}^{2} / \mathrm{g}\right.$, cumulative pore volume $=1.51 \mathrm{~mL} / \mathrm{g}$ ). The silica materials were calcined at $300{ }^{\circ} \mathrm{C}$ for $16 \mathrm{~h}$ under air, followed by at $100{ }^{\circ} \mathrm{C}$ under vacuum for $1 \mathrm{~h}$ and the calcined silicas are hereafter abbreviated with $\mathbf{E V}_{\mathbf{3 0 0}}$ (Sipernat $\AA 50$ ) and $\mathbf{G R}_{\mathbf{3 0 0}}$ (Sylopol $(2408 \mathrm{HT}$ ).

A mild chlorination of the silicas was achieved at ambient temperature in DCM suspension by the addition of an excess $\mathrm{SiCl}_{4}$ and $\mathrm{NEt}_{3}$ (Scheme 1). ${ }^{[8]}$ This method yielded the chlorinated silicas $\mathrm{SiO}_{2}-\mathrm{SiCl}_{2}$ with chlorine surface concentrations $\beta_{\mathrm{Cl}}$ of $6.02 \mu \mathrm{mol} / \mathrm{m}^{2}\left(\mathrm{EV}_{\mathbf{3 0 0}}\right)$ and $6.01 \mu \mathrm{mol} / \mathrm{m}^{2}\left(\mathbf{G R}_{\mathbf{3 0 0}}\right)$. By comparison, this approach leads to higher $\beta_{\mathrm{Cl}}$ values than the chlorination of silica with excess $\mathrm{SiCl}_{4}$ in refluxing toluene $\left[\beta_{\mathrm{Cl}}=2.32 \mu \mathrm{mol} / \mathrm{m}^{2}\left(\mathrm{EV}_{300}\right)\right]$, ${ }^{[7]}$ but lower $\beta_{\mathrm{Cl}}$ values than reached with the gas phase chlorination of silica with neat $\mathrm{SiCl}_{4}$ at high temperature $\left(\mathrm{T}>200^{\circ} \mathrm{C}, \beta_{\mathrm{Cl}}>7 \mu \mathrm{mol} / \mathrm{m}^{2}\right) \cdot{ }^{[9]}$

Treatment of $\mathrm{SiO}_{2}-\mathrm{SiCl}_{2}$ with Lilnd ${ }^{*}$ in a 1:1 solvent mixture of 1,4-dioxane / toluene and moderate heating to $60^{\circ} \mathrm{C}$ for $24 \mathrm{~h}$ led to the indenyl-modified silicas $\mathrm{SiO}_{2}-\mathrm{Si}\left(\mathrm{Ind}^{*}\right)_{2}$. Subsequent lithiation of $\mathrm{SiO}_{2}-\mathrm{Si}\left(\mathrm{Ind}^{*}\right)_{2}$ with $n$-butyllithium and treatment with $\left[\mathrm{HfCl}_{4}(\mathrm{THF})_{2}\right]$ in THF at $-60{ }^{\circ} \mathrm{C}$ yielded the supported pre-catalyst $\mathrm{SiO}_{2}-\mathrm{Si}\left(\mathrm{Ind}^{*}\right)_{2} \mathrm{HfCl}_{2}$ as a yellow powder. The hafnium contents of the materials were determined by ICP-OES analysis to be $\beta_{\mathrm{Hf}}=$ $0.76 \mu \mathrm{mol} / \mathrm{m}^{2}\left(\mathbf{E V}_{\mathbf{3 0 0}}\right.$ and $\left.\mathbf{G R}_{\mathbf{3 0 0}}\right)$. These values are lower than the $\mathrm{Zr}$ content reported by Soga and coworkers in their original report using unsubstituted indenyl and $\mathrm{ZrCl}_{4}(\beta \mathrm{Zr}=$ $\left.1.99 \mu \mathrm{mol} / \mathrm{m}^{2}\right),{ }^{[7 e]}$ which likely reflects the higher steric congestion of the silica surface with the bulky indenyl ligand Ind*.

The successful synthesis of the supported pre-catalyst $\mathrm{SiO}_{2}-\mathrm{Si}\left(\mathrm{Ind}^{*}\right)_{2} \mathrm{HfCl}_{2}$ was followed by X-ray photoelectron spectroscopy (XPS). The $\mathrm{Hf} 4 \mathrm{~d}, \mathrm{Cl} 2 \mathrm{p}$ and $\mathrm{C}$ 1s spectra displayed in Figure 1 confirm the chlorination of the bare $\mathrm{SiO}_{2}$ support surface and the final assembly of the hafnocene complex at the anchoring sites. Starting from the clean $\mathrm{SiO}_{2}$ surface the 
appearance of the $\mathrm{Cl} 2 \mathrm{p}_{3 / 2}$ at $200.3 \mathrm{eV}$ indicates the formation of Si-Cl species in agreement with literature. ${ }^{[10]}$ The final formation of the pre-catalyst is confirmed by a substantial $C$ 1s and $\mathrm{Hf} 4 \mathrm{~d}$ emission as well as a shifted $\mathrm{Cl} 2 \mathrm{p}_{3 / 2}$ signal at $199.3 \mathrm{eV}$ reported for chlorinated hafnocene complexes. ${ }^{[11]} \mathrm{The} \mathrm{Hf} 4 \mathrm{~d} / \mathrm{Cl} 2 \mathrm{p}$ intensity ratio converts to the expected stoichiometry of $1: 2$. Note, that the $\mathrm{Cl} 2 \mathrm{p}$ intensity decrease from the chlorinated $\mathrm{SiO}_{2}$ surface to the precatalyst reflects the loss of anchoring sites during synthesis of the hafnocene complex in agreement with chlorine and hafnium concentrations $\beta_{\mathrm{Cl}}$ and $\beta_{\mathrm{Hf}}$ observed with elemental analysis.

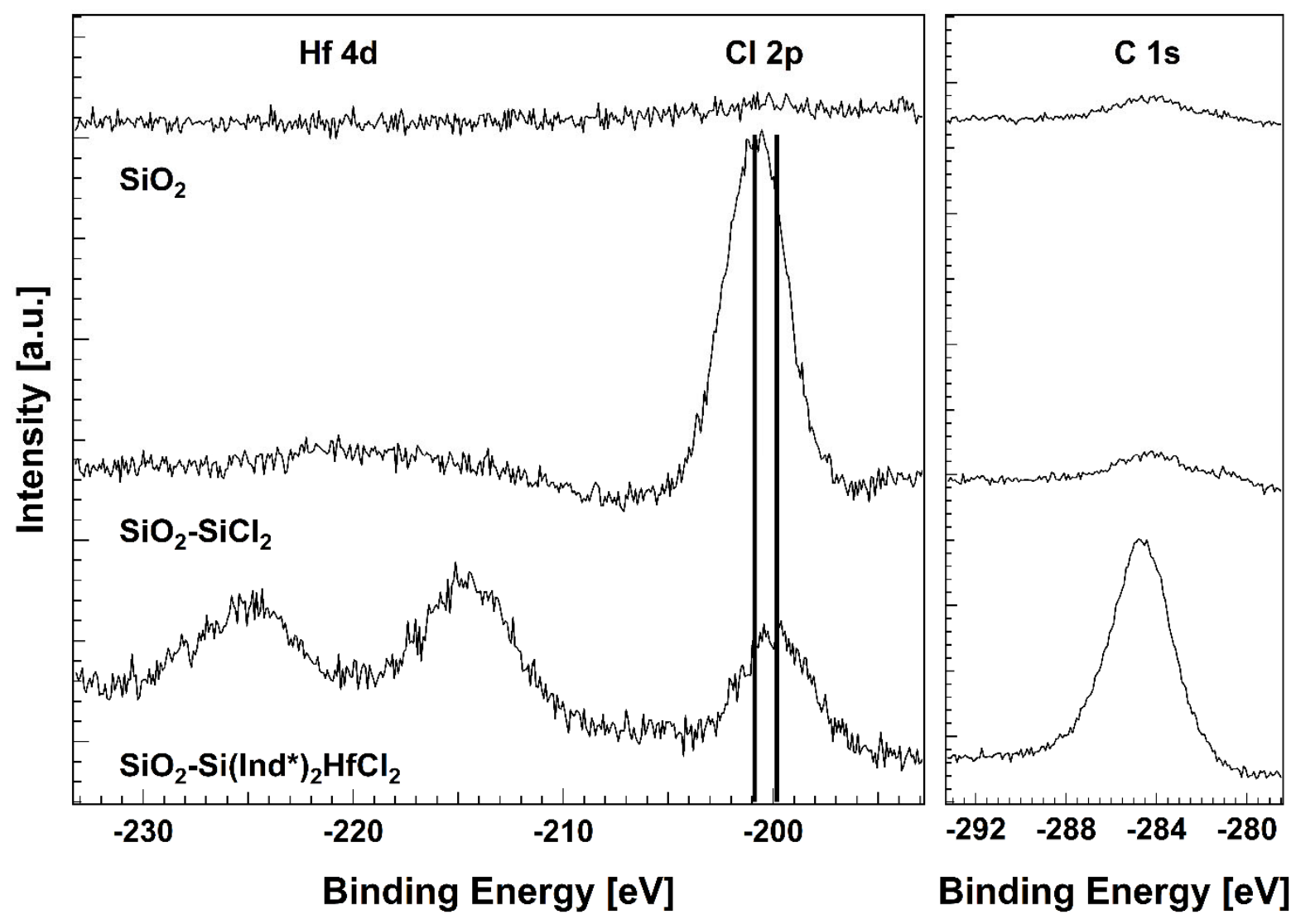

Figure 1. $\mathrm{Hf} 4 \mathrm{~d} / \mathrm{Cl} 2 \mathrm{p}$ as well as $\mathrm{C}$ 1s photoemission spectra obtained from $\mathrm{SiO}_{2}, \mathrm{SiO}_{2}-\mathrm{SiCl}_{2}$ and $\mathrm{SiO}_{2}-\mathrm{Si}\left(\mathrm{Ind}^{*}\right)_{2} \mathrm{HfCl}_{2}$. All spectra have been scaled to the $\mathrm{Si} 2 \mathrm{p}$ peak area originating from the support so that peak intensities reflect the amount of surface atoms.

We tested the slurry-phase polymerization of propene using the immobilized $\mathrm{SiO}_{2}$ $\mathrm{Si}\left(\mathrm{Ind}^{*}\right)_{2} \mathrm{HfCl}_{2}$ pre-catalyst in toluene. For this purpose, the immobilized pre-catalyst was activated with an excess of triisobutylaluminium (TIBA) in toluene at $60^{\circ} \mathrm{C}$ for $1 \mathrm{~h}$ and the polymerization initiated with $\mathrm{CPh}_{3}\left[\mathrm{~B}\left(\mathrm{C}_{6} \mathrm{~F}_{5}\right)_{4}\right]$. Only minor quantities of polymer formed and the attempted extraction of the polymer with 1,2,4-trichlorobenzene (TCB) at $160{ }^{\circ} \mathrm{C}$ yielded only traces of polymeric material for both used silica materials $(<5 \mathrm{mg})$. All further attempts to increase the amount of polymer by increasing either the catalyst loading, the polymerization time, the pressure, the temperature, or the time of pre-catalyst activation showed no 
improvement of the polymer yield. Thus, the catalytic productivity of $\mathrm{SiO}_{2}-\mathrm{Si}\left(\mathrm{Ind}^{*}\right)_{2} \mathrm{HfCl}_{2}$ is markedly lower than that of the indenyl-substituted supported catalyst $\mathrm{SiO}_{2}-\mathrm{Si}(\mathrm{Ind})_{2} \mathrm{ZrCl}_{2}$, for which already low productivities of $2.2-3.6$ gram of polymer per gram of catalyst component were reported. ${ }^{[7 \mathrm{~d}, \mathrm{e}]}$ GPC analysis indicated the presence of polypropylene with a weight average molecular weight $M_{w}$ of $113,000 \mathrm{~g} / \mathrm{mol}$ and a broad dispersity $(\Theta=5.4)$. Unfortunately, a further analysis of the polymer microstructure by ${ }^{13} \mathrm{C}\left\{{ }^{1} \mathrm{H}\right\}$ NMR spectroscopy or thermal analysis was hampered by the only very small quantities of isolated polymer.

Analysis of the supported pre-catalyst before and after polymerization by SEM imaging revealed that agglomerated silica particles are present before the polymerization with individual particle sizes below ca. $25 \mathrm{~nm}$ (Figure 2, left). After the polymerization, the presence of polymer could be clearly confirmed by the SEM images, showing agglomerates of particles with only marginally increased diameters up to a maximum value of roughly $65 \mathrm{~nm}$ (Figure 2 , right). No significant differences were found for the two different silica materials $\mathbf{E V}_{\mathbf{3 0 0}}$ and $\mathrm{GR}_{300}$.
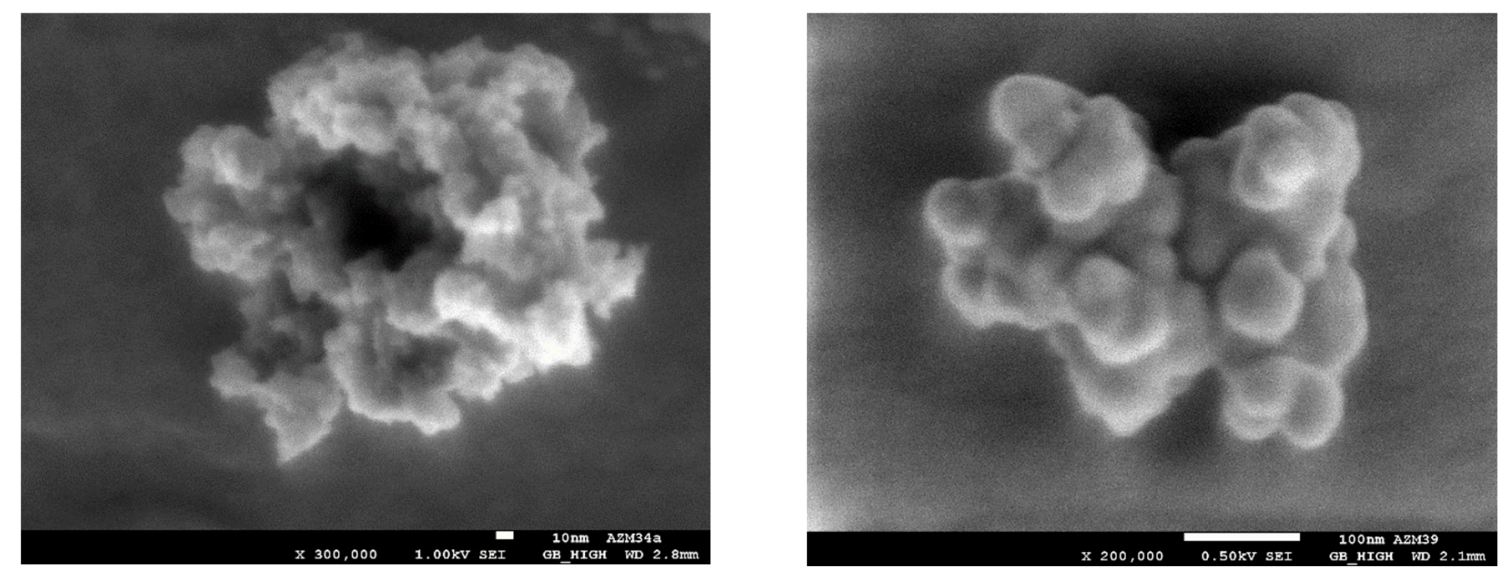

Figure 2. SEM images of $\mathrm{SiO}_{2}-\mathrm{Si}\left(\mathrm{Ind}^{*}\right)_{2} \mathrm{HfCl}_{2}$ before (left) and after (right) the polymerization of propene; used silica: $\mathbf{E V}_{\mathbf{3 0 0}}$ (qualitatively similar images were acquired for $\mathbf{G R}_{\mathbf{3 0 0}}$ ).

We conclude that although XPS and elemental analysis indicate that the supported precatalyst $\mathrm{SiO}_{2}-\mathrm{Si}\left(\mathrm{Ind}^{*}\right)_{2} \mathrm{HfCl}_{2}$ can be synthesized by the sequential approach employed herein, the material is highly inefficient in polymerizing propene, leading to only minor quantities of polypropene, regardless of the reaction conditions and the used silica. SEM imaging shows that the particle diameter only slightly increases after the polymerization, suggesting that any catalytic activity shuts down after initial polymer formation. Presumably, this is a result of the poor accessibility of the catalytically active sites resulting from the steric congestion of the bulky Ind* ligands and the close proximity of the catalyst to the surface, leading to a complete absence of catalytically active sites after the particles are covered with small amounts of polymer. Future studies will now focus on strategies to tether the ultrarigid hafnocene catalyst 
rac-1 which allow for an adjustment of the distance of the catalytically active center and the surface by alteration of the length of the tether. ${ }^{[12]}$

Acknowledgements: M.I.A. thanks the Alexander von Humboldt foundation for a Feodor Lynen return fellowship. We thank Evonik Industries AG and W. R. Grace \& Co. for supply with silica samples and Dr. Asad Asadujjaman for experimental support.

[1] a) X. Cui, W. Li, P. Ryabchuk, K. Junge, M. Beller, Nat. Catal. 2018, 1, 385; b) M. K. Samantaray, E. Pump, A. Bendjeriou-Sedjerari, V. D’Elia, J. D. A. Pelletier, M. Guidotti, R. Psaro, J.-M. Basset, Chem. Soc. Rev. 2018, 47, 8403; c) C. Copéret, A. Comas-Vives, M. P. Conley, D. P. Estes, A. Fedorov, V. Mougel, H. Nagae, F. NúñezZarur, P. A. Zhizhko, Chem. Rev. 2016, 116, 323; d) C. Li, Y. Liu (Eds.), Bridging Heterogeneous and Homogeneous Catalysis. Concepts, Strategies, Applications, Wiley-VCH, Weinheim, 2014; e) P. Barbaro, F. Liguori (Eds.), Heterogenized Homogeneous Catalysts for Fine Chemicals Production, Springer, Dordrecht, Heidelberg, London, New York, 2010; f) R. Anwander, in: Handbook of Heterogeneous Catalysis, $2^{\text {nd }}$ ed. (Eds.: G. Ertl, H. Knözinger, F. Schüth, J. Weitkamp), Wiley-VCH, Weinheim, 2008, chapter 2.4.9, pp. 583-614; g) G. M. Thomas, R. Raja, D. W. Lewis, Angew. Chem. Int. Ed. 2005, 44, 6456.

[2] R. Geyer, J. R. Jambeck, K. L. Law, Sci. Adv. 2017, 3, e1700782.

[3] a) R. Hoff (Ed.), Handbook of Transition Metal Polymerization Catalysts, $2^{\text {nd }}$ ed., John Wiley \& Sons, Hoboken, NJ, 2018; b) M. M. Stalzer, M. Delferro, T. J. Marks, Catal. Lett. 2015, 145, 3; c) I. V. Sedov, V. D. Makhaev, P. E. Matkovskii, Catal. Ind. 2012, 4, 129; d) J. R. Severn, J. C. Chadwick (Eds.), Tailor-Made Polymers. Via Immobilization of Alpha-Olefin Polymerization Catalysts, Wiley-VCH, Weinheim, 2008; e) J. R. Severn, J. C. Chadwick, R. Duchateau, N. Friederichs, Chem. Rev. 2005, 105, 4073; f) G. G. Hlatky, Chem. Rev. 2000, 100, 1347; g) G. Fink, B. Steinmetz, J. Zechlin, C. Przybyla, B. Tesche, Chem. Rev. 2000, 100, 1377.

[4] a) V. Busico, Dalton Trans. 2009, 8794; b) B. Wang, Coord. Chem. Rev. 2006, 250, 242; c) A. Razavi, U. Thewalt, Coord. Chem. Rev. 2006, 250, 155; d) R. Mülhaupt, Macromol. Chem. Phys. 2003, 204, 289; e) R. Blom, A. Follestad, E. Rytter, M. Tilset, M. Ystenes, Organometallic Catalysts and Olefin Polymerization, SpringerVerlag, Berlin, Heidelberg, 2001; f) J. A. Gladysz, Chem. Rev. 2000, 100, 1167; g) L. Resconi, L. Cavallo, A. Fait, F. Piemontesi, Chem. Rev. 2000, 100, 1253; h) W. Kaminsky (Ed.), Metalorganic Catalysts for Synthesis and Polymerization, Springer-Verlag, Berlin, Heidelberg, 1999; i) H. H. Brintzinger, D. Fischer, R. Mülhaupt, B. Rieger, R. M. Waymouth, Angew. Chem. Int. Ed. Engl. 1995, 34, 1143;

[5] a) C. Chen, Nat. Rev. 2018, 2, 6; b) J. Klosin, P. P. Fontaine, R. Figueroa, Acc. Chem. Res. 2015, 48, 2004; c) M. C. Baier, M. A. Zuideveld, S. Mecking, Angew. Chem. Int. Ed. 2014, 53, 9722; d) M. Delferro, T. J. Marks, Chem. Rev. 2011, 111, 2450; e) T. Matsugi, T. Fujita, Chem. Soc. Rev. 2008, 37, 1264;

[6] a) M. R. Machat, D. Lanzinger, A. Pöthig, B. Rieger, Organometallics 2017, 36, 399; b) D. Tranchida, D. Mileva, L. Resconi, B. Rieger, A. Schöbel, Macromol. Chem. Phys. 2015, 216, 2171; c) A. Schöbel, E. Herdtweck, M. Parkinson, B. Rieger, Chem. Eur. J. 2012, 18, 4174;

[7] a) R. Spitz, T. Saudemont, J. Malinge, U.S. patent 6,057,258, 2000; b) K. Soga, Macromol. Symp. 1996, 101, 281; c) K. Soga, Macromol. Symp. 1995, 97, 53; d) K. Soga, H. J. Kim, T. Shiono, Macromol. Rapid Comm. 1994, 15, 139; e) K. Soga, H. J. Kim, T. Shiono, Macromol. Chem. Phys. 1994, 195, 3347.

[8] a) Y. Asakura, Y. Sakamoto, K. Kuroda, Chem. Mater. 2014, 26, 3796; b) P. van der Voort, E. F. Vansant, J. Liq. Chrom. \& Rel. Technol. 1996, 19, 2723; c) C. P. Tripp, M. L. Hair, J. Phys. Chem. 1993, 97, 5693.

[9] K. Unger, W. Thomas, P. Adrian, Kolloid-Z. u. Z. Polymere, 1973, 251, 45.

[10] Y. Paz, S. Trakhtenberg, R. Naaman, J. Phys. Chem. 1994, 98, 13517.

[11] P. Gassman, C. Winter, Organometallics 1991, 10, 1592.

[12] a) C. J. Miller, D. O'Hare, Chem. Comm. 2004, 1710; b) N. Suzuki, J. Yu, N. Shioda, H. Asami, T. Nakamura, T. Huhn, A. Fukuoka, M. Ichikawa, M. Saburi, Y. Wakatsuki, Appl. Catal., A 2002, 224, 63. 